CXXVIII.-Studies in Phototropy and Thermotropy. Part VII. Polymorphic Anisylidenearylamines Produced by Trituration and by the Influence of Actinic Light.

By Alfred Senier and Robert Benjamin Forster.

THIs paper is a continuation of previous communications ( $\mathrm{T}$., 1914, 105, 2462 ; this vol., p. 452) in which the p-hydroxy- and the $p$-hydroxy- $m$-methoxybenzylidenearylamines were studied with special reference to polymorphic varieties produced by trituration. 
The following is a description of a similar study of the $p$-methoxyanalogues.

No instance of phototropy was detected, but most of the compounds gave polymorphic forms by the prolonged influence of actinic light, and most of them were found to be thermotropic. Only one gave a polymorphic variety by trituration. Triboluminescence was entirely absent.

The method of preparation was similar to that previously described, and the terms "the lower temperature" and "the higher temperature" are employed with the same meaning as before (loc. cit.). The compounds dissolve in the ordinary organic solvents, with the exception of dianisylidenebenzidine, which is sparingly soluble in all except nitrobenzene.

Anisylideneaniline, $\mathrm{OMe} \cdot \mathrm{C}_{6} \mathrm{H}_{4} \cdot \mathrm{CH}: \mathrm{N} \cdot \mathrm{C}_{6} \mathrm{H}_{5}$, was first prepared by Schiff (Annalen, 1869, 150,195), who describes it as consisting of golden-yellow plates. Freund and Becker by crystallisation from alcohol obtained colourless needles, which melted at $63^{\circ}$. Our specimen crystallised from light petroleum in colourless needles, which melt at 58-59 $9^{\circ}$ (corr.). This compound is neither thermotropic, nor is it affected by actinic light.

\section{Anisylidenetoluidines, $\mathrm{OMe} \cdot \mathrm{C}_{6} \mathrm{H}_{4} \cdot \mathrm{CH}: \mathrm{N} \cdot \mathrm{C}_{6} \mathrm{H}_{4} \mathrm{Me}$.}

Anisylidene- $m$-toluidine was prepared by Senier and Shepheard (T., 1909, 95, 1952). It is not thermotropic, nor does it polymerise under the influence of actinic light.

Anisylidene-p-toluidine (Steinhart, Annalen, 1887, 241, 340) crystallises from light petroleum in colourless needles, which melt at $92-93^{\circ}$ (corr.) (Steinhart gives $92^{\circ}$ ). It is not thermotropic or affected by actinic light.

\section{Anisylidenexylidines, $\mathrm{OMe} \cdot \mathrm{C}_{6} \mathrm{H}_{4} \cdot \mathrm{CH}: \mathrm{N} \cdot \mathrm{C}_{6} \mathrm{H}_{3} \mathrm{Me}_{2}$.}

Anisylidene-o-4-xylidine crystallises from light petroleum in colourless needles melting at $74-75^{\circ}$ (corr.):

$0 \cdot 1570$ gave $7 \cdot 8$ c.c. $\mathrm{N}_{2}$ at $9^{\circ}$ and $764 \mathrm{~mm} . \quad \mathrm{N}=6.04$.

$$
\mathrm{C}_{16} \mathrm{H}_{17} \mathrm{ON} \text { requires } \mathrm{N}=5.90 \text { per cent. }
$$

Anisylidene-o-4-xylidine assumes a pale yellow colour on keeping. It is thermotropic between "the lower temperature" and the ordinary temperature.

Anisylidene-m-4-xylidine separates from alcohol in pale yellow plates, which melt at $65-66^{\circ}$ (corr.):

0.1770 gave 8.8 c.c. $\mathrm{N}_{2}$ at $12^{\circ}$ and $763 \mathrm{~mm}$. $\mathrm{N}=5.98$.

$\mathrm{C}_{10} \mathrm{H}_{17} \mathrm{ON}$ requires $\mathrm{N}=5 \cdot 90$ per cent. 
Anisylidene-m-4-xylidine is thermotropic between "the lower temperature" and $65^{\circ}$. It is not affected by actinic light.

Anisylidene-p-xylidine crystallises in biscuit-coloured prisms from light petroleum, which melt at $68-69^{\circ}$ (corr.) :

0.2552 gave 12.8 c.c. $\mathrm{N}_{2}$ at $15^{\circ}$ and $761 \mathrm{~mm} . \mathrm{N}=5.95$.

$$
\mathrm{C}_{16} \mathrm{H}_{17} \mathrm{ON} \text { requires } \mathrm{N}=5.90 \text { per cent. }
$$

Anisylidene- $p$-xylidine is thermotropic between "the lower temperature" and the ordinary temperature. On prolonged exposure to light it is converted into a slightly deeper coloured polymorphic form.

A nisylidene- $\psi$-cumidine, $\quad \mathrm{OMe} \cdot \mathrm{C}_{6} \mathrm{H}_{4} \cdot \mathrm{CH}: \mathrm{N} \cdot \mathrm{C}_{6} \mathrm{H}_{2} \mathrm{Me}_{3}$, separates from carbon tetrachloride in very pale yellow prisms, which melt at $66^{\circ}$ (corr.):

0.2372 gave $11 \cdot 4$ c.c. $\mathrm{N}_{2}$ at $13^{\circ}$ and $754 \mathrm{~mm} . \mathrm{N}=5 \cdot 69$.

$$
\mathrm{C}_{17} \mathrm{H}_{19} \mathrm{ON} \text { requires } \mathrm{N}=5.53 \text { per cent. }
$$

Anisylidene- $\psi$-cumidine is thermotropic between "the lower temperature" and about $65^{\circ}$. Prolonged exposure to sunlight produces no visible change.

Anisylidenechloroanilines, $\mathrm{OMe} \cdot \mathrm{C}_{6} \mathrm{H}_{4} \cdot \mathrm{CH}: \mathrm{N} \cdot \mathrm{C}_{6} \mathrm{H}_{4} \mathrm{Cl}$.

Anisylidene-o-chloroaniline crystallises from alcohol in almost colourless needles, which melt at $61^{\circ}$ (corr.):

0.2046 gave 10.0 c.c. $\mathrm{N}_{2}$ at $17^{\circ}$ and $762 \mathrm{~mm}$. $\mathrm{N}=5 \cdot 77$.

$$
\mathrm{C}_{14} \mathrm{H}_{12} \mathrm{ONCl} \text { requires } \mathrm{N}=5 \cdot 71 \text { per cent. }
$$

Anisylidene-o-chloroaniline is not affected by prolonged exposure to sunlight, but is thermotropic between the ordinary temperature and about $60^{\circ}$.

Anisylidene-m-chloroaniline separates from light petroleum in flat, biscuit-coloured prisms, which melt at $54^{\circ}$ (corr.):

0.2034 gave $9 \cdot 9$ c.c. $\mathrm{N}_{2}$ at $14^{\circ}$ and $764 \mathrm{~mm}$. $\mathrm{N}=5 \cdot 82$.

$\mathrm{C}_{14} \mathrm{H}_{12} \mathrm{ONCl}$ requires $\mathrm{N}=5 \cdot 71$ per cent.

Anisylidene- $m$-chloroaniline is thermotropic between "the lower temperature" and the ordinary temperature. Prolonged exposure to sunlight converts it into a slightly deeper-coloured polymorphic form.

Anisylidene-p-chloroaniline crystallises from light petroleum in colourless plates melting at $93-94^{\circ}$ (corr.):

0.2063 gave $10 \cdot 4$ c.c. $\mathrm{N}_{2}$ at $19^{\circ}$ and $761 \mathrm{~mm}$. $\mathrm{N}=5.90$.

$\mathrm{C}_{14} \mathrm{H}_{12} \mathrm{ONCl}$ requires $\mathrm{N}=5 \cdot 71$ per cent.

Anisylidene-p-chloroaniline is neither thermotropic nor is it affected by prolonged exposure to sunlight. 
A nisylidenebromoanilines, $\mathrm{OMe} \cdot \mathrm{C}_{6} \mathrm{H}_{4} \cdot \mathrm{CH}: \mathrm{N} \cdot \mathrm{C}_{6} \mathrm{H}_{4} \mathrm{Br}$.

Anisylidene-m-bromoaniline separates from light petroleum in colourless needles, which melt at $61-62^{\circ}$ (corr.):

0.1978 gave 8.2 c.c. $\mathrm{N}_{2}$ at $11^{\circ}$ and $754 \mathrm{~mm} . \quad \mathrm{N}=4.94$.

$\mathrm{C}_{14} \mathrm{H}_{12} \mathrm{ONBr}$ requires $\mathrm{N}=4 \cdot 83$ per cent.

Anisylidene- $m$-bromoaniline is not thermotropic. On prolonged exposure to sunlight, it is converted into a very pale biscuitcoloured polymorphic variety.

Anisylidene-p-bromoaniline crystallises from carbon tetrachloride in very faint yellow needles, which melt at $120^{\circ}$ (corr.). It becomes somewhat deeper in colour on keeping:

0.2654 gave 10.9 c.c. $\mathrm{N}_{2}$ at $11^{\circ}$ and $753 \mathrm{~mm}$. $\mathrm{N}=4.89$.

$\mathrm{C}_{14} \mathrm{H}_{12} \mathrm{ONBr}$ requires $\mathrm{N}=4 \cdot 83$ per cent.

Anisylidene- $p$-bromoaniline is thermotropic between the ordinary temperature and about $118^{\circ}$. On exposure to sunlight, it is converted into a deep canary-yellow-coloured polymorphic form.

\section{Anisylideneaminophenols, $\mathrm{OMe} \cdot \mathrm{C}_{6} \mathrm{H}_{4} \cdot \mathrm{CH} \cdot \mathrm{C}_{6} \mathrm{H}_{4} \cdot \mathrm{OH}$.}

Anisylidene-o-aminophenol was first prepared by Haegele (Ber., $1892,25,2755$ ), who describes it as crystallising from dilute alcohol in brownish-yellow needles melting at $89^{\circ}$. Our specimen, crystallised from light petroleum, has the same appearance and melting point. Its solution exhibits fluorescence.

Anisylidene-o-aminophenol is thermotropic between "the lower temperature" and about $85^{\circ}$. Prolonged exposure to sunlight converts it into a slightly deeper-coloured polymorphic form.

Anisylidene-p-aminophenol was also prepared by Haegele (loc. cit.), who describes it as crystallising from alcohol in yellow prisms, melting at $188^{\circ}$. Our specimen, crystallised from xylene, consists of buff-coloured needles, which have the same melting point. It is not affected by sunlight, but exhibits thermotropy between the ordinary temperature and about $185^{\circ}$.

Anisylidene- $p$-anisidine, $\mathrm{OMe} \cdot \mathrm{C}_{6} \mathrm{H}_{4} \cdot \mathrm{CH}: \mathrm{N} \cdot \mathrm{C}_{6} \mathrm{H}_{4} \cdot \mathrm{OMe}$, was first prepared by Hantzsch and Schwab (Ber., 1901, 34, 832), who describe it as shining, white plates, melting at $142^{\circ}$. By crystallisation from carbon tetrachloride we obtained colourless needles melting at $146-147^{\circ}$ (corr.). Prolonged exposure to sunlight converts it into a very pale biscuit-coloured polymorphic form. It exhibits thermotropy between the ordinary temperature and about $145^{\circ}$; at the latter temperature it has a pale biscuit colour. 


\section{Anisylideneaminobenzoic Acids, $\mathrm{OMe}^{\cdot} \mathrm{C}_{6} \mathrm{H}_{4} \cdot \mathrm{CH}: \mathrm{N} \cdot \mathrm{C}_{6} \mathrm{H}_{4} \cdot \mathrm{CO}_{2} \mathrm{H}$.}

Anisylidene-o-aminobenzoic acid crystallises from xylene in fine, yellow needles, which melt at $145^{\circ}$ (corr.) :

0.1504 gave $7 \cdot 0$ c.c. $\mathrm{N}_{2}$ at $15^{\circ}$ and $766 \mathrm{~mm}$. $\mathrm{N}=5.56$.

$$
\mathrm{C}_{15} \mathrm{H}_{13} \mathrm{O}_{3} \mathrm{~N} \text { requires } \mathrm{N}=5.49 \text { per cent. }
$$

Anisylidene-o-aminobenzoic acid is not affected by sunlight. It is thermotropic between the ordinary temperature and about $145^{\circ}$. Its colour is deepest at about $120^{\circ}$.

A nisylidene-m-aminobenzoic acid separates from xylene in biscuitcoloured needles, which melt at $151-152^{\circ}$ (corr.). A yellow variety which melted at the same temperature was obtained by crystallising from alcohol :

0.1472 gave 6.8 c.c. $\mathrm{N}_{2}$ at $11^{\circ}$ and $766 \mathrm{~mm} . \quad \mathrm{N}=5.59$. $\mathrm{C}_{15} \mathrm{H}_{13} \mathrm{O}_{3} \mathrm{~N}$ requires $\mathrm{N}=5.49$ per cent.

Anisylidene- $m$-aminobenzoic acid is dimorphous. Trituration converts the biscuit-coloured variety into the yellow-coloured variety. The paler-coloured variety is scarcely acted on by sunlight, but exhibits thermotropy between the ordinary temperature and about $150^{\circ}$. The deeper-coloured variety is converted into a brownish-yellow, polymorphic form by prolonged exposure to sunlight. It reverts to the paler-coloured variety at about $70^{\circ}$.

A nisylidene-p-aminobenzoic acid crystallises from alcohol in pale yellow needles, which melt at $196-197^{\circ}$ (corr.) :

0.1168 gave 5.4 c.c. $\mathrm{N}_{2}$ at $12^{\circ}$ and $765 \mathrm{~mm}$. $\mathrm{N}=5.57$.

$\mathrm{C}_{15} \mathrm{H}_{13} \mathrm{O}_{3} \mathrm{~N}$ requires $\mathrm{N}=5.49$ per cent.

Anisylidene-p-aminobenzoic acid is not acted on by sunlight, but is thermotropic between the ordinary temperature and about $195^{\circ}$.

Dianisylidenebenzidine, $\mathrm{OMe} \cdot \mathrm{C}_{6} \mathrm{H}_{4} \cdot \mathrm{CH}: \mathrm{N} \cdot \mathrm{C}_{6} \mathrm{H}_{4} \cdot \mathrm{C}_{6} \mathrm{H}_{4} \cdot \mathrm{N}: \mathrm{CH} \cdot \mathrm{C}_{6} \mathrm{H}_{4} \cdot \mathrm{OMe}$, crystallises from nitrobenzene in yellow plates melting at $257-258^{\circ}$ (corr.). It is only sparingly soluble in other usual organic solvents :

0.2052 gave $12 \cdot 0$ c.c. $\mathrm{N}_{2}$ at $21^{\circ}$ and $753 \mathrm{~mm}$. $\mathrm{N}=6.73$. $\mathrm{C}_{28} \mathrm{H}_{24} \mathrm{O}_{2} \mathrm{~N}_{2}$ requires $\mathrm{N}=6.67$ per cent.

Dianisylidenebenzidine is thermotropic between "the lower temperature" and about $250^{\circ}$. At higher temperatures the colour change is well marked. It is converted into a somewhat deepercoloured polymorphic form by prolonged exposure to sunlight.

Anisylidenenaphthylamines, $\mathrm{OMe} \cdot \mathrm{C}_{6} \mathrm{H}_{4} \cdot \mathrm{CH}: \mathrm{N} \cdot \mathrm{C}_{10} \mathrm{H}_{7}$.

Anisylidene- $\alpha$-naphthylamine was prepared by Pope and Fleming (T., 1908, 93, 1916), who describe it as crystallising from alcohol 
THE ROTATORY DISPERSIVE POWER OF ORGANIC COMPOUNDS. 1173

in colourless plates melting at $100-101^{\circ}$. Our specimen, crystallised from light petroleum, consists of pale yellow plates melting at this temperature. It is thermotropic between "the lower temperature" and about $100^{\circ}$. Prolonged exposure to sunlight converts it into a slightly deeper-coloured polymorphic form.

Anisylidene- $\beta$-naphthylamine was prepared by Steinhart (loc. cit.). Our specimen, crystallised from light petroleum, consists of pale yellow plates, which melt at $99^{\circ}$ (corr.) (Steinhart gives $\left.98^{\circ}\right)$. It is thermotropic between "the lower temperature" and about $95^{\circ}$. Prolonged exposure to sunlight converts it into a slightly deeper-coloured polymorphic form.

UNIVERSITY COLLEGE,

GaLWAY

[Received, July 10th, 1915.] 